\title{
P372: Reduction of HAl Legionella pneumophilia pneumonia and Pseudomonas aeruginosa sepsis by control with water supply
}

\author{
LP Andersen ${ }^{1 *}$, A-MB Hellesoe ${ }^{1}$, B Rubenhagen $^{2},{\mathrm{M} \mathrm{H} ø \mathrm{~g}^{2}}^{2}$ \\ From 2nd International Conference on Prevention and Infection Control (ICPIC 2013) \\ Geneva, Switzerland. 25-28 June 2013
}

\section{Introduction}

Water associated hospital acquired infections with Legionella pneumophila and Pseudomonas aeruginosa is a problem in many Hospital settings. At Rigshospitalet there was a high incidence of HAI $L$. pneumophilia pneumonia compared to other Danish hospitals. I addition several dialyze patients with $P$. aeruginosa septicemia could only be explained by infection through the dialyze catheter during showers.

\section{Objectives}

Is it possible to reduce the number of water associated HAI by systematical control of water supply and focused infection control precautions in wards at risk?

\section{Methods}

Total germ count and Legionella germ count was measured in shower water and drinking water twice a year. Laboratory and standardized in vivo tests were done on shower water. Incidence rates of HAI L. pneumophilia pneumonia, $P$. aeruginosa, Acinetobacter baumanii and Stenotrophamonas maltophilia septicemia in hospitalized patients were recorded.

\section{Results}

Both the incidence rates of HAI L. pneumophilia pneumonia, $P$. aeruginosa septicemia in hospitalized patients were reduced more than $50 \%$ within a few years.

Figures cannot be shown.
'Infection Control 9101, Copenhagen University Hospital, Rigshospitalet, Copenhagen, Denmark

Full list of author information is available at the end of the article

\section{Conclusion}

Systematical control of water supply and focused infection control precautions in wards at risk can reduce the number of water associated HAI over time.

\section{Disclosure of interest}

None declared.

\section{Author details}

'Infection Control 9101, Copenhagen University Hospital, Rigshospitalet Copenhagen, Denmark. ${ }^{2}$ Clinical Microbiology, Copenhagen University Hospital, Rigshospitalet, Copenhagen, Denmark.

Published: 20 June 2013

doi:10.1186/2047-2994-2-S1-P372

Cite this article as: Andersen et al:: P372: Reduction of HAI Legionella pneumophilia pneumonia and Pseudomonas aeruginosa sepsis by control with water supply. Antimicrobial Resistance and Infection Control 2013 2(Suppl 1):P372.

Submit your next manuscript to BioMed Central and take full advantage of:

- Convenient online submission

- Thorough peer review

- No space constraints or color figure charges

- Immediate publication on acceptance

- Inclusion in PubMed, CAS, Scopus and Google Scholar

- Research which is freely available for redistribution

Submit your manuscript at www.biomedcentral.com/submit 